\title{
European Higher Education Area and the Introduction of a Quality Assurance Program in Greek Universities: Is Policy-Oriented Learning Present?
}

George Stamelos ${ }^{1}$ and Aggelos Kavasakalis ${ }^{2}$

$\approx$ This paper aims to investigate the production (or not) of policy-oriented learning during the establishment and implementation of a specific policy program in the policy sub-system of the Greek university as well as the interpretation of the existence (or not) of policy-oriented learning. The theoretical tools were drawn mainly from the theoretical work of Sabatier and Jenkins-Smith, termed the 'advocacy coalition framework (ACF)'. The Greek university is therefore considered to be a policy subsystem in which actors form coalition networks that share policy core beliefs and values, and engage in coordinated action in order to translate these beliefs and values into public policy. Thirty-five semi-structured interviews were used for the production of data, in combination with policy paper analysis.

Keywords: Greek higher education; Higher education policy; Policy analysis; Quality assurance

$1{ }^{\star}$ Corresponding Author. Department of Primary Education and Educational Sciences (PTDE), University of Patras, Greece; stamelos@upatras.gr

2 Department of Primary Education and Educational Sciences (PTDE), University of Patras and Geitonas School, Greece 


\section{Evropski visokošolski prostor in vpeljava programa za zagotavljanje kakovosti na grških univerzah - ali obstaja produkcija s politikami usmerjenega učenja?}

George Stamelos* In Aggelos Kavasakalis

$\propto$ Cilj prispevka je po eni strani raziskati produkcijo (ali odsotnost) s politikami (policy) usmerjenega učenja med pripravo in implementacijo določenega strateškega (policy) programa v grškem univerzitetnem podsistemu, po drugi strani pa interpretacijo obstoja (ali neobstoja) s politikami usmerjenega učenja. Teoretično izhodišče je izpeljano na podlagi teorije zagovorniške koalicije (advocacy coalition framework - ACF), ki sta jo podala Sabatier in Jenkins - Smith. Tako lahko grško univerzo obravnavamo kot strateški (policy) podsistem, v katerem akterji oblikujejo koalicijske mreže, ki delijo ista ključna strateška (policy) prepričanja in vrednote ter se vključujejo v koordinirane akcije $\mathrm{z}$ namenom, da bi ta prepričanja in vrednote prenesli v javne politike (policy). Za potrebe raziskave je bilo opravljenih 35 polstrukturiranih intervjujev v kombinaciji z analizo strateških (policy) dokumentov.

Ključne besede: grško visoko šolstvo, visokošolske politike (policy), analiza politik (policy), zagotavljanje kakovosti 


\section{Theoretical choices}

\section{An overview of the framework}

The advocacy coalition framework (ACF) was initially designed in the late 198 os by Paul Sabatier and Hank Jenkins-Smith to help explain advocacy coalition structure and behaviour, the role of scientific and technical information in policy (policy-oriented learning) and policy change in policy subsystems. The ACF has since been applied worldwide to analyse the formation and implementation of policy programs through policy network analysis in different policy regimes and in different policy sectors. ${ }^{3}$ Among these works, some educational policy programs have been analysed.

The ACF considers mapping out policy to be a continuous process without a concrete beginning and end. The content of reforms is influenced by the permanently altered coalition networks, which represent different policy beliefs, values and interests. Coalition networks are defined as groups of actors coordinating their behaviour to some extent in order to achieve a common, or complementary, political objective (Hula, 1999). As Sabatier claims, the ACF recognises

'the importance of problem perception; shifts in elite and public opinion concerning the salience of various problems; periodic struggles over the proper locus of governmental authority; incomplete attainment of legallyprescribed goals; and an iterative process of policy formulation, problematic implementation, and struggles over reformulation' (Sabatier, 1988, p. 130).

A basic principle of this framework is that coalitions possess a well-developed belief system that is organised on three levels: deep core beliefs; policy core beliefs and secondary beliefs. ${ }^{4}$ This system of beliefs organises fundamental values and perceptions and connects them to the causes of policy problems and consequently to suitable approaches for their resolution (Zafonte \& Sabatier, 2004, p. 78).

A general depiction of the policy process inside the ACF framework is as follows:

'[A] few people perceive a [policy] problem or source of dissatisfaction. They identify one or more causes and then propose one or more policies to deal with the specific causes. Thus, a policy belief system is developed and employed in the policy process [...] Those who feel themselves aggrieved by

3 The links below provide readers with a categorisation of ACF's applications worldwide. http://www.des.ucdavis.edu/faculty/Sabatier/Sabatier.htm http://www.ucdenver.edu/academics/colleges/SPA/BuechnerInstitute/Centers/WOPPR/ACF/ Pages/AdvocacyCoalitionFramework.aspx It has to be mentioned that Paul Sabatier died on 3 February 2013.

4 For further study: Leach et al. (2005); Sabatier and Jenkins-Smith (1999), Sabatier (1988). 
the proposed policy have a number of options [...] Thus the aggrieved actors construct an alternative, conflicting belief system and, with it, weigh in against the initiative of the first group. The original group normally responds to these challenges, thereby initiating the process of strategic interaction. In this process each group attempts to (a) convince key policy decision makers that its belief system is the appropriate one, leading to the preferred policy choice, or failing that, (b) to restructure the policy space as perceived by key decision makers in order to achieve a policy outcome as closely approximating their own position as possible' (Jenkins-Smith, 1988, p. 172-173).

In the case of high levels of conflict, wherein advocacy coalitions in the subsystem rigidly adhere to the existing belief system, repeated attempts to ignore or refute compelling analytical criticisms result in the loss of analytical credibility (Heintz \& Jenkins-Smith, 1988, p. 270).

The ACF proposes a set of hypotheses regarding: (a) formation and action of advocacy coalitions; (b) production of policy-oriented learning during the establishment and implementation of a policy programme; and (c) policy change due to policy sub-system internal events and external parameters.

This paper focuses on the determination of data that is related to the production (or not) of policy-oriented learning during the implementation of the policy programme for quality assurance in Greek universities. Consequently, we will focus only on the ACF hypotheses that are related to policy-oriented learning.

\section{Policy oriented learning}

Heclo (1974, p. 306) believes that policy-oriented learning refers to relatively enduring alterations of thought or behavioural intentions that result from experience during the implementation of a programme and that are concerned with the attainment (or revision) of policy objectives. Policy-oriented learning also involves perceptions concerning external dynamics and increased knowledge of the state of the specific policy issue parameters and the factors affecting them.

It has to be mentioned, however, that policy-oriented learning is unlikely by itself to significantly alter the core attributes of a policy program. However, it is 'an important process in understanding changes in at least the secondary aspects of governmental action programs and may occasionally even lead to a revision of core aspects in the absence of perturbations from beyond the subsystem' (Sabatier, 1988, p. 149).

However, what can be regarded as policy-oriented learning? Jenkins-Smith and Sabatier say that this acquisition of knowledge concerning a policy program can be a variety of things, such as: 
'(a) improving one's understanding of the state of variables defined as important by one's belief system (or, secondarily, by competing belief systems) [...] (b) refining one's understanding of logical and causal relationships internal to a belief system [...] (c) identifying and responding to challenges to one's belief system. Exogenous events, a loss of political resources, opponents' activities, or a variety of other factors may force proponents to revise their belief systems by incorporating some new elements' (Jenkins-Smith \& Sabatier, 1993, p. 42-43).

The acquisition of (policy) knowledge via political experience can be separated into two categories: (1) policy knowledge that is acquired within an advocacy coalition as a result of the interaction of actors in a political process taking place among the coalition's networks, and (2) the knowledge acquired between the conflicting networks' coalitions. Regarding policy knowledge between conflicting networks' coalitions, there are three basic parameters that affect policy-oriented learning: the level of conflict, the nature of the analytical forum and the analytical tractability of policy issue (Heintz \& Jenkins-Smith, 1988; Jenkins- Smith, 1985, 1988).

The general hypotheses that ACF provide us to search for and analyse the existence (or not) of policy-oriented learning during the establishment and implementation of a policy program are:

'(a) policy-oriented learning across belief systems is most likely when there is an intermediate level of informed conflict between the two coalitions, (b) problems for which accepted quantitative data and theory exist are more conducive to policy-oriented learning across belief systems than those in which data and theory are generally qualitative, quite subjective or altogether lacking, (c) problems involving natural systems are more conducive to policy-oriented learning across belief systems than those involving purely social or political systems because, in the former, many of the critical variables are not themselves active strategists and because controlled experimentation is more feasible and (d) policy-oriented learning across belief systems is most likely when there exists a forum that is prestigious enough to force professionals from different coalitions to participate and when it is dominated by professional norms' (Jenkins-Smith \& Sabatier, 1993, p. 50, 52, 54; Sabatier \& Jenkins-Smith, 1999, p. 124-125).

As can be seen from both categories, policy-oriented learning results in a change in the belief system of coalitions. In the possible absence of this production, particularly in policy themes that cause considerable tension, we usually have the 
phenomenon of a deaf dialogue between competing advocacy coalition networks.

It has to be mentioned, however, that policy-oriented learning is not the only way for a policy change to take place during the establishment and implementation of a policy program in a specific policy subsystem (Heintz, 1988, p. 216). At this point, it is necessary for the understanding and interpretation of the analysis of this paper to depict the ACF view about policy change, although this is not the focus of this paper.

According to ACF, policy change could be understood through two different processes:

- The first process is related to the coalitions' efforts from within the subsystem to defend and promote their own belief systems in the policy programs. In this process, a prominent, but not exclusive role is played by the acquisition of policy knowledge via political experience (policy-oriented learning).

- The second process could result in policy change by alternations that are external to the subsystem, such as: (1) changes in socioeconomic conditions, (2) changes in public opinion, (3) a change in the systemwide governing coalition, or (4) outputs from other subsystems. Moreover, as Sabatier and Jenkins-Smith state, ${ }^{5}$ these non-cognitive opportunities for policy change should be skilfully exploited by the minority coalition if it is to gain power, since the dominant coalition will almost certainly resort to a variety of delaying strategies in an effort to ride out the shock (Sabatier \& Jenkins-Smith, 1993, p. 211-236).

\section{Implementation of a quality assurance program in Greek universities and ACF policy-oriented learning}

The research was conducted through the lenses of theoretical tools that link policies and procedures with actors and policy networks. In the policy area of education, besides the existence of interests and interest groups, there are powerful value systems and (educational) beliefs that are instrumental in the actions of networks. Therefore, it was necessary that a theoretical tool that could express and analyse the conjunction of interests, values and belief systems be used in this research. In accordance with the ACF, the formation of and interaction between different advocacy coalition networks are not analysed simply in terms of interests and power relations but also in terms of belief systems and values that policy networks possess.

An additional feature that makes the ACF a useful analytical tool in this

5 In a future paper, they also include another non-cognitive change that may cause policy change: 'turnover in personnel constitutes a second non-cognitive source of change that can substantially alter the political resources of various coalitions and thus policy decisions' (Sabatier \& JenkinsSmith, 1999, p. 123). 
research topic is that advocacy coalition analysis has often been used when the formation and implementation of a policy program creates tension and conflicts between opposing networks. This is present, as will be highlighted, during the formation and implementation of a quality assurance system in Greek universities.

\section{Quality assurance on a European level}

In 1998, the 'Recommendation of the Council of 24th September 1998 on European cooperation in quality assurance in higher education' was published. It recommended that transparent evaluation systems of quality should be supported and created (Official Journal of European Communities, 1998, p. 57-58). Due to this recommendation, the quality assurance of European universities came to the forefront of the European education policy agenda. Moreover, in the Bologna process at the second ministerial communiqué in Prague 2001, there was extensive mention of quality assurance and the ministers 'recognised the vital role that quality assurance systems play in ensuring high quality standards and in facilitating the comparability of qualifications throughout Europe' (Bologna Process, 2001, p. 2).

In the Bergen communiqué of 2005, ministers of education adopted the proposals of the report 'Standards and Guidelines for Quality Assurance in the European Higher Education Area (ESG)' for the three levels of standards and guidelines on quality assurance that was submitted by the E4 group (Bologna process, 2005, p. 5). The levels of standards and guidelines in the report were internal evaluation, external evaluation and the rules that will condition the creation and operation of the independent national quality assurance agencies.

\section{Quality assurance in the Greek higher education system}

The developments in the European Higher Education Area (EHEA) concerning QA put pressure at a national level on the Greek higher education system for the establishment of a quality assurance law. Prior to 2003, an institutionalised evaluation system had not been implemented. ${ }^{6}$ In that year, the ministry of education (MoE) published a Draft-Law for the enactment of a quality assurance system (MoE - Draft Law, 2003). The MoE expected to pass the law by the end of 2003, but the reaction among academics along with national elections and a change of administration halted the process.

The efforts of the new administration concentrated on the passing of the law for Quality Assurance in 2005. In essence, this law provides for the implementation of evaluation procedures (as part of a QA system) in two phases, internal and external,

6 Nevertheless, it has to be mentioned that most Greek universities had been evaluated either by the 'Institutional Evaluation Programme (IEP)' by EUA or through other European national evaluation programs. 
in Greek higher education institutions every four years. Internal evaluation is carried out by the academic members of each department. A unit of internal evaluation is formed and is responsible for the completion of internal evaluation procedures and the passing on of the internal evaluation report to an independent authority. External evaluation is organised by an independent authority, the Hellenic Quality Assurance Agency for Higher Education (ADIP). A final report on external evaluation then has to be published in accordance with Law 3374/2005. This law was passed in July 2005, despite reactions in universities (Kavasakalis \& Stamelos, 2011, p. 38). The law is entirely in accordance with the 'ESG' report and the procedures followed by ENQA.?

\section{Methodology}

Two methodological tools were used to carry out the wider research. The main methodological tool was the conducting of qualitative semi-structured interviews. These interviews were conducted during 2009, four years after the voting of the specific law (Law 3374/ 2005) and two years after the operation of the independent body responsible for the QA procedures. This was necessary since the beliefs of actors (individual or collective) should be investigated after a period of time has passed from the formation and implementation of the institutionalised QA system in European higher education systems (in early 2000). The analysis of research findings beyond the scope of this paper was completed two years later, at the end of 2011.

The discussion topics of the semi-structured interviews were decided on, taking into consideration issues that resulted from public consultations with regard to the establishment and implementation of a quality assurance policy programme in Greek universities. ${ }^{8}$

Policy discourse analysis also took place for the analysis of the related policy program. In general discourse, analysis is the study of change or the bringing into being of a social reality through the production, distribution and consumption of texts. However, the discourses of policy documents are not neutral. They usually have a hidden relation between proposed policy process and power struggle among actors. ${ }^{9}$ This is the reason that policy discourse analysis often focus on points of conflict and change in their field of research, as they are indicators of power relations.

7 The independent authority (ADIP) started its operation two years later, at the end of 2007.

8 The 'axes of discussion' were: the Greek University today; educational policies for the 'European university'; the notion of quality and evaluation of universities; Law 3374/2005; conditions for public dialogue concerning quality assurance in the Greek university, and the way the dialogue was conducted; proposals for a modern Greek university.

9 As Foucault states about power in a policy process: 'power [...] which is assumed to exist universally in a concentrated or diffused form, does not exist. Power exists only when it is put into action, even if, of course, it is integrated into a disparate field of possibilities brought to bear upon permanent structures. This also means that power is not a function of consent' (Foucault, 1982 , p. 219-220). 
In this research, the analysis of policy documents questioned the specific policy-making processes, the power relations between policy actors (individual or collective) and managed to initially reveal the networks ${ }^{10}$ and key-actors that are usually active in the policy subsystem of the Greek university and finally point to the possible shifts and changes of power inside and between active to this policy program networks.

Subsequently, thirty five semi-structured interviews were carried out. ${ }^{11}$ From an elaboration of the produced texts, the policy beliefs of each interviewee were structured and categorised. Finally, the composition of the networks' belief systems and the belief systems of the advocacy network coalitions was realised.

\section{Findings}

At the beginning of the data analysis, it is necessary to make a general clarification. It is believed that it is not necessary for all actors who belong to a network (or a network coalition) to have identical belief systems. However, the activation of each actor inside a network means that, in general, the belief system of the network expresses him/her. Therefore, we will attempt to determine the common component in the beliefs of our interviewees (who belong to the same network) for the necessary production of each network's beliefs system.

From the research and the initial analysis, it emerged that to the network coalition that is in favour of the specific policy programme belong the classic ${ }^{12}$ networks: 'Governmental network' (this network belongs the network of political party New Democracy (ND) and the Ministry of Education, since it is the political authority responsible for the implementation of education policy programmes), 'PASOK', 'INE-GSEE' and 'SEV-IOVE', as well as the key-actors I.21, I.23 and the experts on the specific policy programme (i.e. on quality assurance systems in universities) I.28, I.16. Respectively, to the anti-policy networks' coalition belong the networks 'POSDEP', 'KKE' and 'SYRIZA', as well as the experts I.13 and I.31.

This initial analysis brought to light important differentiations in all categories of the belief systems of the two advocacy coalitions. Moreover, the tension that is

10 Networks active during the quality assurance policy program: 'Rectors' Conference'; 'POSDEP'

(Professional and trade union association of the university academic staff); 'AR.SI.' (Left Today); 'GURF' (Greek University Reform Forum); 'Initiative' (Initiative for the reform and upgrade of Greek university); 'KIPAN' (Movement for University Upgrade); 'INE-GSEE' (General Confederation of Workers of Greece with the specialised Institute of Work of GSEE); 'SEV-IOVE' (Hellenic Federation of Enterprises (SEV) and especially its institute of research named Foundation for Economic and Industrial Research - IOVE); and finally the networks of parliamentary political parties in Greece: 'ND' (neo-liberal party); 'PASOK' (socialist party); 'KKE' (Greek communist party); 'SYRIZA' (left wing party).

11 In this paper, the interviewees are referred to as I.1, I.2 etc.

12 Networks active in the subsystem for a much wider period of time than the period in question, which saw the formation and implementation of the quality assurance policy program. 
produced concerning beliefs that are related to the European education policies for higher education is exceptionally acute, since these differences appear to go beyond the examined policy theme and acquire a wider ideological background. The wider research also reveals that 'new'13 networks emerge and become active during the examined period. From the initial analysis of the belief systems of these networks, it appeared that 'GURF, 'KIPAN' and 'Initiative' emerged within the pro-policy coalition, whereas the network 'AR.SI.' played the role of policy broker. ${ }^{14}$

\section{Findings concerning policy-oriented learning within coalitions}

A first question concerns the possible connection between the emergence of new networks and the production of (policy) knowledge, mainly within the in favour' coalition due to the actions and interactions of new networks' members. To answer this question, a comparison is made of the beliefs system of the 'classic' networks inside this coalition and the beliefs system of the 'new' networks inside the pro-policy coalition. The following table (Table 1) summarises this comparison. It has to be mentioned that none of the 'new' networks possess beliefs that would enable them to act inside the anti-policy coalition. Therefore, there is no need for a similar comparison between 'classic' and 'new' networks within the anti-policy coalition to take place..$^{15}$

13 New networks are those networks that were activated during the specific policy programme: 'GURF' (Greek University Reform Forum); 'Initiative' (Initiative for the reform and upgrade of Greek university); 'KIPAN’ (Movement of University Upgrade) and 'AR.SI.' (Left Today).

14 For further study cf. Kavasakalis, 2011, pp. 332-374.

15 Two general remarks that facilitate the reader throughout this part of the paper since it analyses only a part of the wider research:

- Concerning the absence of deep core beliefs: this level of beliefs is largely the product of childhood socialisation, it involves very general normative and ontological assumptions about human nature, fundamental values such as liberty and equality and therefore it is very unlikely to change during the establishment and implementation of a policy program (Leach et al., 2005, p. 192).

- Concerning the notion of quality referred to in the table, Harvey and Green (1993), in their discussion of the relationship between quality and standards in higher education, identify different aspects of quality. These different notions of quality obviously have different implications not only for the methods used to measure quality but also for the beliefs and values concerning the role of university in modern society. Quality as excellence: this notion of quality underpins the elitist view of the high quality of an 'Oxbridge' education, which equates it to excellence and high standards (Harvey \& Knight, 1996). Quality as fitness for purpose: this requires that a product or service fulfil customer's needs, requirements or desires. In a university's mission of statement its goals are clarified, and at a lower level these goals are defined in the program's aims. In this notion of quality, universities are required to say what they do, do what they say and then prove it to an external assessor. Quality as value for money: it is a popular notion for quality that equates quality with value for money. Since all public sectors ought to be accountable, this notion gives the right to the state, the major financier of higher education, to demand efficiency and effectiveness. Quality as transformation: in the context of quality in higher education, transformation is not restricted to apparent physical transformation but also to cognitive transcendence with the provider 'doing something to the customer rather than just doing something for the customer' (Harvey \& Green, 1993, p. 24). 
Table 1. Comparison of belief systems between 'classic' and 'new' networks within the pro-policy coalition.

\begin{tabular}{|c|c|}
\hline $\begin{array}{l}\text { Pro-policy networks' Coalition } \\
\text { 'Classic' networks }\end{array}$ & $\begin{array}{l}\text { Pro-policy networks' Coalition } \\
\text { 'New' networks }\end{array}$ \\
\hline \multicolumn{2}{|l|}{ Policy Core Beliefs } \\
\hline \multicolumn{2}{|l|}{ Role and operation of university } \\
\hline $\begin{array}{l}\text { - We have a more democratic institution due } \\
\text { to expansion policies. But these policies ei- } \\
\text { ther had no planning or were implemented } \\
\text { under the influence of powerful political } \\
\text { pressures. This creates problems such as } \\
\text { high economic cost, and in many cases the } \\
\text { difficulty for university campus culture to } \\
\text { exist } \\
\text { - A looser framework-law is needed so that } \\
\text { real autonomy and independence become } \\
\text { possible } \\
\text { - Main characteristics of the university: inter- } \\
\text { nalisation, transparency, social accountabil- } \\
\text { ity, quality assurance } \\
\text { - Connection of the university with the } \\
\text { needs of society } \\
\text { - Autonomy and independence need to be } \\
\text { balanced with social accountability }\end{array}$ & $\begin{array}{l}\text { - The university is a public, mass institution and } \\
\text { its goal should be its internationalisation and } \\
\text { the increase in its flexibility (through institu- } \\
\text { tional changes) } \\
\text { - Upgrading the university cannot be combined } \\
\text { with the stifling framework-laws and the } \\
\text { stranglehold of the ministry } \\
\text { - There is no independence today. The univer- } \\
\text { sity has to be able to make decisions on all } \\
\text { issues, and the State has to determine the } \\
\text { public finance in connection with certain data, } \\
\text { such as the results of evaluation } \\
\text { - Increase in public finance in parallel with a } \\
\text { change in the financing model } \\
\text { - Aid to research with an increase in financing } \\
\text { along with simultaneous aid for excellence } \\
\text { and competition for the attraction of ad- } \\
\text { ditional financing }\end{array}$ \\
\hline \multicolumn{2}{|l|}{ Notion of quality in the university } \\
\hline $\begin{array}{l}\text { - The most powerful version of quality is } \\
\text { 'quality as value for money'. Many net- } \\
\text { works also adhere to the version 'quality as } \\
\text { fitness for purpose' } \\
\text { - The notion of quality is a complex one } \\
\text { since it is related to the overall policy } \\
\text { planning of each university. However, this } \\
\text { difficulty should not be used as an excuse } \\
\text { for not starting evaluation processes } \\
\text { - Transparency, promotion of research and } \\
\text { excellence are elements of quality }\end{array}$ & $\begin{array}{l}\text { - The difficulty in defining quality is recognised } \\
\text { - Versions of quality: 'quality as fitness for } \\
\text { purpose' (for the strengthening of university } \\
\text { independence and autonomy) and 'quality as } \\
\text { value for money' (for more effective invest- } \\
\text { ment in universities) }\end{array}$ \\
\hline \multicolumn{2}{|l|}{ Evaluation and the university } \\
\hline $\begin{array}{l}\text { - In favour of an institutionalised evalua- } \\
\text { tion system, with internal evaluation as an } \\
\text { obligatory stage } \\
\text { - The most important stage of an evaluation } \\
\text { process is the 'after'. Evaluation findings } \\
\text { should be used by the ministry and the uni- } \\
\text { versity so that the evaluation system will } \\
\text { not end up being just a formal, bureau- } \\
\text { cratic process } \\
\text { - The university is nowadays a massive, } \\
\text { internationalised institution. Therefore, } \\
\text { institutionalised evaluation that follows } \\
\text { international standards is an important } \\
\text { policy tool }\end{array}$ & $\begin{array}{l}\text { - In favour of an institutionalised evaluation } \\
\text { system that will be aimed at the improvement } \\
\text { of university quality } \\
\text { - Evaluation should not just be an idea a theory. } \\
\text { It should become a tool for quality assurance } \\
\text { in the university and for the identification of } \\
\text { problems. It should be, therefore, a tool for } \\
\text { the implementation of any education policy } \\
\text { - Evaluation should avoid the trap of uniformity } \\
\text { and be differentiated depending on the } \\
\text { particularities of each higher education insti- } \\
\text { tution and each scientific subject/area } \\
\text { - The evaluation system should follow interna- } \\
\text { tional standards and practices }\end{array}$ \\
\hline
\end{tabular}


European Education policies in the university

- The Bologna process and, more generally, European education policies (EEP) 'push' the Greek university towards positive reforms. It is positive that the Greek university attempts, as part of these processes, to follow international developments

- EEP result in the internationalisation of the Greek university and research

- Due to European education programmes, the Greek university becomes, for the first time, a centre for international research

- There are a few negative effects due to EEP, but the balance is positive

- The reaction to EEP stems from (a) ideological reasons and (b) incomplete knowledge and analysis of EEP

European Education policies for Quality Assurance in the university

- Quality assurance procedures at a European level are a central line of action in the formation of EHEA. They promote co-operation, mobility, and recognition procedures

- In addition, the comparable evaluation and quality assurance procedures offer the transmission of valid information about universities and national higher education systems
- The formation of the European Higher Education Area (EHEA) is a significant educational, political, and cultural issue, and Greek universities should participate in its development

- Due to EEP, reforms are being promoted such as internationalisation, increase of mobility, and the improvement of the connection between the university, society, and the labour market
- The quality assurance line of action in EEP is directly connected to the recognition of degrees or any part of one's studies, and more generally to the transfer of information between universities and European higher education systems

Secondary Beliefs

Law 3374/2005

- The Law is, in general, in agreement with the standards and guidelines for quality assurance that have been proposed at Bergen

- A basic disadvantage of the Law is that its formation is connected to Greece's international commitments and not to a 'bottom-up' procedure

- The Law promotes social accountability and the notion of 'quality as fitness for purpose' along with an initial recording of issues and problems without any sanctions

Structures for the concretisation and implementation of the Law

- The initial phase of implementation has difficulties, a slow pace and many reactions, but the important point is that it has already begun

- Reactions to this initial phase are intense and excessive since they stem from ideological and political factors

- A 'quality culture' should be present for the effective implementation of the Law

- Often, the critique of the material that ADIP has produced, is that it is undertaken without a thorough study of these proposed guidelines and indicators
- The 'new' networks are clearly in favour of the Law and of an institutionalised evaluation system.

- The independence of the Hellenic Quality Assurance Agency for Higher Education (ADIP) must be reinforced

- In the phase of external evaluation, the presence of an external reviewer from another country should be obligatory
- The preparation of guidelines and indicators by the ADIP, although essential, presents problems in its implementation. The material is overly detailed, and thus increases bureaucracy and standardisation

- The intense reactions are due to political and 'corporate' reasons 
From the comparison of core and secondary beliefs between 'classic' and 'new' networks inside the pro-policy coalition, as they are presented in the previous table, it can be seen that there are no considerable changes in the belief systems between the two networks. Therefore, it could be concluded that no refinement of the belief systems takes place due to strategic interaction, and consequently there is a lack of production of policy-oriented learning inside this coalition.

As a result, the appearance of 'new' networks is not related to policy-oriented learning on the specific policy issue. Hence, a further question concerns the reason for the appearance of these networks, and the difference they bring with their activation on the policy issue. An answer to this might be the activation of previously non-activated members of the subsystem due to the continuing intensity and conflict during the establishment and implementation of the policy programme. Indeed, from the analysis of policy documents produced by these networks, ${ }^{16}$ it emerges that these new actors decided to act in order to decrease the particular intensity and to strengthen the pro-policy coalition with their activation. Furthermore, some interviewees believe that the activation of these actors was not connected with the refinement of (policy) knowledge but was mainly connected with actions that were related to the decrease of intensity and the change of the political climate in the sub-system:

'The trade-union body (POSDEP) with its beliefs and actions has created a climate among many academics that what POSDEP supports and promotes in the public dialogue does not represent them and their beliefs' (I.5 - anti-policy networks' coalition).

'My opinion is that new networks played an important role in changing the climate inside universities, and they led to developments, which in my opinion, were very positive, as was proved afterwards with the change in the trade-union network' (I.37 - pro-policy networks' coalition).

\section{Findings concerning policy-oriented learning between coalitions}

For the research concerning the production of (policy) knowledge

16 Initiative of Academics for the Reform and the Upgrade of the Public University (2007). Conference for the Upgrading of Public Universities: targets and prerequisites: final results (Athens, March 2007); Declaration of 'Initiative' (2007). Declaration of Initiative for the reform and upgrade of the Greek university, Athens, Retrieved June 2009 from http://greek-academicsinitiative.blogspot.com/2006/og/blog-post_23.html; Founding declaration of 'KIPAN' (2004). The founding declaration of the Movement for University Upgrade, Athens, Retrieved June 2009 from http://www.ntua.gr/anavathmisi/; KIPAN (2005). Beliefs concerning evaluation, Athens, Retrieved June 2009 from http://www.ntua.gr/anavathmisi/files/08062005/KIPAN SxedioTheseon_axiologisi_3_06_05.pdf; Greek University Reform Forum (2005). 'Manifesto' - Initial declaration of the forum: 'A few thoughts on Universities', Retrieved June 2009 from http://www.sci.ccny.cuny.edu/ themis/greekuniversityreform/ 
between the conflicting network coalitions, the factors that are related to this type of policy-oriented learning were analysed, i.e. the level of conflict, the nature of the analytical forums, and the analytical tractability of policy issue (Heintz \& Jenkins-Smith, 1988; Jenkins- Smith, 1985, 1988).

From the data analysis, it may be argued that there was a general lack of dialogue culture, the discussion/debates were usually full of slogans, and remarkably intense. Especially during the period of conflict, opinions that go beyond the logic of conflict were rarely heard. The pro-policy coalition and many policy brokers ${ }^{17}$ were of the opinion that the attitude of resistance and not that of likely conciliation was dominant. ${ }^{18}$ Indicatively, relevant quotations from the texts that were produced from the analysis of interviews with the corresponding annotation.

The dialogue was full of slogans, claiming that responsibility was of the networks or the media:

'I lived through [this] from the inside. It did not surprise or impress me that the dialogue between actors was very intense and superficial' (I.32 'governmental' network).

'Systematic, devastating propaganda by the Media which systematically discredits the public university has been continuously present since the ' 80 's whenever there is public dialogue concerning a university-related theme. The media have no scientific approach to policy actions connected with the Bologna process and more generally with the European university' (I.24 - 'POSDEP').

Lack of dialogue culture and culture of synthesis/formation of education policy:

'Social dialogue is usually a line of parallel monologues. This is a conclusion formed by someone studying what has been written in the past few years by academics on issues concerning policies for universities. [But] public dialogue ought to follow the notion of synthesis' (I.12 - 'INE-GSEE').

'I have the feeling that we do not know anything about education policy.

17 Policy brokers. In a policy program where conflicting coalition networks are active, as Sabatier says 'there will almost certainly be a category of actors (here termed 'policy brokers') whose dominant concern is with keeping the level of political conflict within acceptable limits and with reaching some 'reasonable' solution to the problem. [...] The distinction between 'advocate' and 'broker' is, however, a continuum. Many brokers will have some policy bent, while advocates may show some serious concern with system maintenance' (Sabatier, 1988, p. 141).

18 As an example, see a few related articles in Greek newspapers: (Koumantos, 2005; Lavdas, 2005; Maistros, 2005; Markatos, 2005; Milonakis, 2005; Theotokas, 2005; Venieris, 2005; Xrysochoou, 2006). 
I have to mention that, after all this tension, no representative from any political party came to discuss and analyse the policy subject with us. [...] Therefore, there was no real dialogue and analysis' (I.10 - 'Rectors' Conference').

The logic of resistance and not of synthesis was dominant in the public debates:

'Resistance always exists. It says that you may change but without disturbing anything. This is, I believe, due to the lack of real dialogue inside universities about the needs that lead to these changes' (I.8 - 'AR.SI.').

'Have you heard 'POSDEP' say yes to any change? I do not believe that there is in the area of the university a more conservative force [...] I felt offended when I heard [central actors of POSDEP] playing the role of academics' representatives and saying things that were from the 18 th century' (I.4 - 'governmental' network).

Consequently, the above findings, in combination with the wider intense conflict between the two coalitions, lead to the conclusion that the conditions for public dialogue did not facilitate the production of policy-oriented learning between the conflicting network coalitions.

From the research and data analysis on the nature and characteristics of the analytical forums that took place during this policy issue, it appears that: (i) in the debates on official dialogue there was a considerable homogeneity of beliefs between the networks that ultimately participated in the official dialogue and (ii) in the 'open' forums intense conflict was usually present. As a result, no new (policy) knowledge capable of influencing the developments in the specific policy issue was produced.

Characteristically, two of our interviewees said:

'Public dialogue has many levels: the official level, the level of the Rectors' Conference, the level of the academic community and finally the level of the general, open public debates. I know that inside all universities at the Senate level, and in certain universities also at other levels, such discussions took place. There was also discussion in the trade-union body (POSDEP). [...] Whether there was a considerable production of new ideas is questionable. But, even if some ideas/proposals have been produced, it is also [questionable] whether the government took them into account' (I.9 - 'KIPAN').

'I have also signed various documents (texts), as my other colleagues did, in an institutional context. I also signed some texts that I considered to be close to my opinions. But however positive these movements/ 
actions were (as they were good for achieving a conciliatory perception and attitude in the things that we discuss) I do not know if there was a positive enough environment for them to result in a synthesis' (I.22 'Rectors' Conference').

Finally, from data analysis on the particular characteristics of the policy issue itself (the analytical tractability of the issue), it emerged that the notion of quality central to the policy issue is a multilevel and abstract notion. Furthermore, the theoretical discussion on this notion is encountered as an especially complex discussion. In addition, the discussions and analyses with regard to the values that the university as an institution should serve as well as its role in modern society appeared to have only qualitative and multidimensional characteristics. Moreover, these discussions conceal and include an intense ideological background. This creates unfavourable conditions for the production of scientific analysis and conclusions relevant to the subparts that compose the specific policy issue.

Indicatively, two quotations concerning the analytical tractability of the policy issue:

'The usual reply [when there is a discussion about evaluation]: who will be the one that will evaluate me, when I have 10-12 years' service in this institution [...] As you may understand a climate, a perception and more generally a mentality exists among a percentage of academics that creates negative conditions [for evaluation processes]' (I.22 - 'Rectors' Conference').

'And because they cannot formulate their positions with regard to this [the defence of vested interests], what do they present as a serious argument in public dialogue? They invoke some values that are supposedly under pressure, or in danger due to the proposed changes [of the policy programme]. As a result, we are led into a dialogue that has nothing to do with the substance of the policy programme' (I.29 - 'SEV-IOVE').

\section{Conclusions}

From the previous analysis, a few conclusions could be summarised:

1) The conditions for public dialogue concerning the QA policy program in Greek universities did not facilitate the production of (policy) knowledge. As has been shown, a lack of dialogue culture was permanently present, and the debates concerning the QA program were usually full of slogans and tensions.

2) The activation of 'new' networks during the establishment and implementation of the QA program in Greek universities took place without the 
production of policy-oriented learning. This activation seemed to be a reaction to, in their opinion, inflexible and dead-end policy practices of the antipolicy networks' coalition and simultaneously seemed to be related to the growth of the strategic movements of networks inside the pro-policy coalition, aimed at the inversion of forces and power correlations in the policy subsystem of the Greek university.

3) The analytical tractability of the policy issue related to the QA policy program is rather low: the notion of quality, central to this program is a multilevel and abstract notion, the discussions and analysis concerning the values and the modern role of the university appeared to have only qualitative and multidimensional characteristics. Moreover, the specific policy issue has an intense ideological background. And as Jenkins-Smith says:

'[When the] analysis is subject to a great deal of uncertainty, and not surprisingly different analysts are prone to provide estimates and analytical conclusions quite at variance with one another [and in general] the less well developed an area of inquiry, the more elusive the necessary data, and (above all) the weaker the agreement on theory and data, the greater the analytical intractability. Such intractability, in turn, admits a greater degree of analytically plausible difference of opinion among analysts' (Jenkins-Smith, 1988, p. 194).

Therefore, as has been shown in this paper, the formation and implementation of a policy program (in our case the QA program in Greek universities) without the parallel production of policy-oriented learning inside or between the opposing advocacy coalition networks takes place under certain conditions. Given this finding, certain questions emerge: what is the meaning and the result for the relationship between policy and society when there is an absence of policy-oriented learning along with the policy changes that result from the formation and implementation of a new policy program? Could this perhaps be an indication of a mismatch between society and political word? Could this be related (as an example) to the social crisis and social political delegitimisation that we are experiencing today? These wider issues ought to be investigated in the future.

\section{References}

Bologna Process (2001). Towards the European Higher Education Area, Communiqué of the meeting of European Ministers in charge of Higher Education. Prague, 19 May 2001.

Bologna process (2005). The European Higher Education Area - Achieving the Goals. Communiqué of the Conference of Ministers responsible for Higher Education. Bergen 19/20-5-2005. 
Declaration of 'Initiative' (2007). Declaration of the Initiative for the reform and upgrade of the Greek university. (in Greek). Retrieved June 202012 from http://greek-academics-initiative.blogspot. com/2006/og/blog-post_23.html Foucault, M. (1982). The subject and power. In H. Dreyfus \& P. Rabinow (Eds.), Michel Foucault: Beyond structuralism and hermeneutics (pp. 208-226). Brighton: Harvester Press.

Founding declaration of 'KIPAN' (2004). The founding declaration of the Movement for University Upgrade. (in Greek). Retrieved June 202012 from http://www.ntua.gr/anavathmisi/ Greek University Reform Forum (2005). 'Manifesto' - Initial declaration of the forum: 'A few thoughts on Universities'. (in Greek). Retrieved June 252012 from http://www.sci.ccny.cuny.edu/ themis/ greekuniversityreform/

Harvey, L., \& Green, D. (1993). Defining quality. Assessment \& Evaluation in Higher Education, 18(1), 9-34.

Harvey, L., \& Knight, P. (1996). Transforming Higher Education. Buckingham: SRHE/Open University Press.

Heclo, H. (1974). Social Policy in Britain and Sweden. New Haven: Yale Univ. Press.

Heintz, Th. (1988). Advocacy coalitions and the OCS leasing debate: A case study in policy evolution. Policy Sciences, 21, 213-238.

Heintz, Th., \& Jenkins-Smith, C. H. (1988). Advocacy coalitions and the practice of policy analysis. Policy Sciences, 21, 263-277.

Hula, K. W. (1999). Lobbying together: Interest group coalitions in legislative politics. Washington, DC: Georgetown University Press.

Initiative of Academics for the Reform and the Upgrade of the Public University (2007). Conference for the Upgrading of Public Universities: targets and prerequisites: final results. Athens, March 2007 (in Greek).

Jenkins-Smith, H. (1985). Adversarial Analysis in the Bureaucratic Context. In P. Brown (Ed.), Advocacy Analysis. Baltimore: University of Maryland Press.

Jenkins-Smith, H. (1988). Analytical debates and policy learning: analysis and change in the federal bureaucracy. Policy Sciences, 21, 169-211.

Jenkins-Smith, H., \& Sabatier, P. (1993). The Dynamics of Policy-Oriented Learning. In P. Sabatier \& H. Jenkins-Smith (Eds.), Policy Change and Learning: An Advocacy Coalition Approach. Boulder: Westview Press.

Kavasakalis, A., \& Stamelos, G. (2011). 20 years of efforts to establish and implement a Quality Assurance System in Greek Higher Education. Mediterranean Journal of Social Sciences, 2(3), 35-45. Kavasakalis, A. (2011). The establishment of a Quality Assurance mechanism on Greek University: the formation of Advocacy Coalition Policy Networks in the sub-system of Greek University. PhD thesis. University of Patras, Greece.

KIPAN (2005). Beliefs concerning evaluation. (In Greek). Retrieved June 252012 from http://www. ntua.gr/anavathmisi/files/08062005/KIPAN_SxedioTheseon_axiologisi_3_06_05.pdf Koumantos, G. (2005). Behold the Evaluation. 'Kathimerini', 29/5/2005 (in Greek). 
Lavdas, K. (2005). Evaluation and independence-autonomy in the Greek universities. 'Eleftherotypia', $17 / 3 / 2005$ (in Greek).

Law 3374 (2005). Quality Assurance in Higher Education. Credit Transfer and Accumulation System. Diplomas Supplement. Official Gazette of the Hellenic Republic, First Issue, No. 189, 2 August 2005.

Leach, W., Lubell, M., Pelkey, N., \& Sabatier, P. A. (2005). Theoretical Frameworks Explaining Partnerships Success. In P. A. Sabatier et al. (Eds.), Swimming upstream: collaborative approaches to watershed management. Cambridge (Mass.): The MIT Press.

Maistros, G. (2005). Higher Education Selling Out. 'Kyriakatiki Eleftherotypia', 12/6/2005 (in Greek).

Markatos, N. (2005). (About) Quality and Evaluation of universities: Measuring excellence or irrationality?. 'Eleftherotypia', 11/4/2005 (in Greek).

Milonakis, D. (2005). University: quality evaluation and independence. 'Eleftherotypia', 6/5/2005 (in Greek).

MoE - Draft Law (2003). National system of quality assurance and evaluation of higher education, Institutes of life-long learning, International Greek University and other provisions. Athens: Ministry of Education, September 2003 (in Greek).

Official Journal of European Communities (1998). Recommendation of the Council of 24th September 1998 on European cooperation in quality assurance in higher education, (98/561/EC), L $270 / 56,07.10 .1998$.

Sabatier, A. P., \& Jenkins-Smith, C. H. (1988). Symposium editors' introduction. Policy Sciences, 21, 123-127.

Sabatier, A. P. (1988). An advocacy coalition framework of policy change and the role of policyoriented learning therein. Policy Sciences, 21, 129-168.

Sabatier, P., \& Jenkins-Smith, H. (1999). The Advocacy Coalition Framework: An Assessment. In P. Sabatier (Ed.), Theories of the Policy Process. Boulder, CO: Westview Press.

Theotokas, N. (2005). Accreditation and Quality Assurance of Education Services. 'Avgi', 29/5/2005 (in Greek).

Venieris, G. I. (2005). All the problems should be recorded. 'Eleftherotypia', 7/2/2005 (in Greek). Xrysochoou, J. (2006). It is time for claims and not for signatures. 'Eleftherotypia', 29/12/2006 (in Greek).

Zafonte, M., \& Sabatier, P. (2004). Short-Term Versus Long-Term Coalitions in the Policy Process: Automotive Pollution Control, 1963-1989. The Policy Studies Journal, 32(1), 75-107. 


\section{Biographical note}

Stamelos Georgios is a professor at the University of Patras (Greece). His research interests are on Higher Education Policy, European Education Policy, Quality Assurance in Higher Education and Teacher Education. His works are published in Greek, French, English and Spanish. He is a member of the Hellenic Quality Assurance and Accreditation Agency (HQAA). He is the coordinator of the Interuniversity Network "Higher Education Policy" (http:// hepnet.upatras.gr).

Kavasakalis Aggelos holds a $\mathrm{PhD}$ in education policy from University of Patras, Greece. He is a professor at Geitonas School (www.geitonas.edu. gr) and a rapporteur on programs for the employment and vocational training, Manpower Employment Organization (OAED). He is an active member of the Interuniversity Network "Higher Education Policy Network". His interests on research field are on European Educational Policies, Higher Education Policy and Quality Assurance policies in Higher Education. 